\title{
Managing Peer-to-Peer Cooperation Using Knowledge-Based Trust and Encouraging the Willingness to Share Tacit Knowledge
}

\author{
LaJuan Perronoski Fuller \\ Trident University International, Cypress, CA, USA \\ Email: lajuan.fuller@my.trident.edu
}

How to cite this paper: Fuller, L. P. (2021). Managing Peer-to-Peer Cooperation Using Knowledge-Based Trust and Encouraging the Willingness to Share Tacit Knowledge. Open Journal of Business and Management, 9, 1246-1262.

https://doi.org/10.4236/ojbm.2021.93067

Received: April 13, 2021

Accepted: May 25, 2021

Published: May 28, 2021

Copyright $\odot 2021$ by author(s) and Scientific Research Publishing Inc. This work is licensed under the Creative Commons Attribution International License (CC BY 4.0).

http://creativecommons.org/licenses/by/4.0/

\begin{abstract}
Despite leaders' investment in knowledge management practices, $76 \%$ of U.S. employees are hesitant to share tacit knowledge with co-workers. Researchers have suggested that willingness to share hinders the tacit knowledge transfer process. Employees become unwilling to share tacit knowledge with others due to cooperation and competition. The aim of this research is to understand the role of peer-to-peer cooperation on willingness to share tacit knowledge (WSTK). A total of 250 U.S. employees were sampled to measure knowledge-based trust (KBT) on WSTK. Pearson correlation and linear regression were used to investigate KBT and WSTK. Results indicated that KBT significantly predicted WSTK. Employee age and same-gender interactions did not influence the KBT-WSTK relationship. It was concluded that leaders and managers who promote KBT relationships are likely to encourage WSTK and create advantages over competitors.
\end{abstract}

\section{Keywords}

Management, Knowledge Sharing, Tacit Knowledge Transfer, Knowledge Creation

\section{Introduction}

Leaders invest heavily in knowledge management (KM) practices that encourage tacit knowledge sharing among employees. The KM community widely accepts that willingness to share tacit knowledge creates organizational knowledge (Edwards et al., 2017). However, Pan et al. (2018) reported that, despite leadership investment in KM practices, $76 \%$ of U.S. employees are hesitant to share tacit knowledge with co-workers. 
The mind is the repository of tacit knowledge and employees may be unwilling to share their knowledge with others (Kwahk \& Park, 2016; Okazaki \& Campo, 2017). This is known in literature as knowledge hiding. Knowledge hiding is more than the lack of sharing; it is intentionally withholding of tacit knowledge (Bogilovic et al., 2017; Connelly \& Zweig, 2015). Holste and Fields (2010) suggested that willingness to share hinders tacit knowledge transfer process. Because $76 \%$ of U.S. employees are hesitant to share tacit knowledge, it is important to investigate $\mathrm{KM}$ practices to encourage employees' willingness to share knowledge with co-workers.

Tacit knowledge is implanted in employee actions, habits, and cases of personal activity (Nonaka, 1994) and cannot be articulated and fixed in documents (Balogun \& Gabriel, 2015). Tacit knowledge is generally transferred through social interactions known as knowledge sharing (Agarwal \& Islam, 2014; Kennedy et al., 2012; Shao et al., 2016). Knowledge sharing can occur in leader-subordinate (Liu \& Phillips, 2011; Razmerita \& Nielsen, 2016) and in horizontal peer-to-peer exchanges (e.g., Connelly et al., 2016). However, understanding of the willingness to share tacit knowledge is still limited in the business arena (Gupta et al., 2020). This study investigates how peer-to-peer cooperation techniques may advance the literature on the willingness to share tacit knowledge.

Cooperation and competition can take place concurrently and on two separate continua (Bengtsson et al., 2010). Leaders consider cooperation and competition as equally valuable for improving peer-to-peer interactions (Bengtsson \& Raza-Ullah, 2016; Vasin, 2020). The overall role of cooperation and competition are not fully understood (Dorn et al., 2016). However, investigating the role of cooperation and competition may begin to explain U.S. employee hesitation to share tacit knowledge with co-workers.

This study focuses on peer-to-peer cooperation to influence willingness to share tacit knowledge. Cooperation requires peers to work together, meet expectations, and attain organizational goals. Peer expectations regarding another's conduct develop a trust relationship (Lewicki et al., 1998). Because trust is built on positive expectations and willingness to be vulnerable (McEvily \& Tortoriello, 2011; Li et al., 2015), it is appropriate to measure peer-to-peer cooperation.

McAllister's (1995) research on cognition-based and affect-based trust has dominated organizational studies, leading to the position that affect-based trust influences knowledge exchange more than does cognition-based trust (Levin \& Cross, 2004; Zhou et al., 2010). Furthermore, affect-based trust influences willingness to share tacit knowledge (Holste \& Fields, 2010). However, there is limited literature on how other forms of trust may influence willingness to share tacit knowledge.

Lewicki and Bunker's (1996) concept of professional relationship trust (PRT) may be an alternative measurement of peer-to-peer cooperation. PRT stages consist of calculus-based, identity-based, and knowledge-based trust derived 
from romantic relationship development, according to Boon and Holmes (1991). Calculus-based trust (CBT) is based on written policies, procedures, punishments, and rewards for maintaining trust. KM community considers this explicit knowledge where information is written in documents, guidelines, and policies (Holste \& Fields, 2010). So, calculus-based trust is not appropriate for measuring peer-to-peer cooperation. Employees rarely reach the identity-based trust (IBT) stage due to employee turnover and the age of the business (Lewicki \& Bunker, 1996). Thus, IBT is more suitable for studies on possible mediating or moderating affects on employee turnover and company age as a control variable. However, knowledge-based trust (KBT) has several conditions that may expand understanding of peer-to-peer cooperation techniques to advance the literature on willingness to share tacit knowledge.

First, KBT suggests that, through repeated peer-to-peer interactions, employees gather enough information to predict peer behavior. Research supports this premise that trust builds predictability between employees (Dietz \& den Hartog, 2006). Employees at the KBT stage can predict both trustworthy and untrustworthy behaviors. Similarly, pervious research has confirmed that trust reflects a person's intentionality (McEvily \& Zaheer, 2005; McEvily et al., 2003); and considers trust-as-choice (Li et al., 2015). Thus, employees who exhibit KBT attributes are likely to display tacit knowledge-sharing behavior.

This study used the uncertainty reductions theory (Berger \& Bradac, 1982; Berger \& Calabrese, 1975). The uncertainty reductions theory suggests that the more one knows a person, the more one can predict that person's behavior. This is consistent with the conditions of KBT. The aim is to advance understanding of factors that influence willingness to share tacit knowledge (Gupta et al., 2020), applying social identity theory (SIT). SIT has been widely used to examine peer-to-peer trust relationships (Carnahan et al., 2017; Rupp \& Mallory, 2015). Therefore, employees who exhibit KBT attributes will have a positive relationship with willingness to share tacit knowledge. Leaders and managers will benefit by acquiring insight into knowledge sharing practices to maintain sustainability and advantage over competitors (Gagné et al., 2019).

\section{Literature Review}

Nonaka et al. (1994) defined knowledge management as a process of creating, dispersing, utilizing, and administering knowledge. This implies a multidisciplinary approach to achieve business objectives by incorporating knowledge (Okazaki \& Campo, 2017). However, the current investigation focused on methods of dispersing tacit knowledge within the management process through knowledge sharing. Knowledge sharing is significant for organizations to maintain a competitive advantage (Park \& Gabbard, 2018). However, academics have argued that specialized knowledge is a valuable and scarce resource (Hitchen et al., 2017; Kumi \& Sabherwal, 2018). This research adapts the definition of tacit knowledge as personal, difficult to formalize, and difficult to communicate and 
manage (Shen \& Wang, 2017).

\subsection{Willingness to Share Tacit Knowledge}

Polanyi (1966: p. 4) described tacit knowledge as "we know more than we can tell." Tacit knowledge is uniquely formed by individual beliefs, attitudes, emotions, and intuition. Certain aspects of tacit knowledge reside in the subconscious and are inaccessible for articulation. However, employees can use face-to-face interactions to share tacit knowledge (Nonaka \& Takeuchi, 1995; Spender \& Grant, 1996; Sweeney, 1996; Teece, 2000; Teece et al., 1997). Conversely, employees may encounter feelings of risk and uncertainty when faced with sharing and using tacit knowledge. This research applied uncertain reductions theory to approach known issues associated with tacit knowledge sharing behaviors.

Employees require certain levels of personal relationship (Epstein, 2000; Nonaka et al., 1994) and willingness to participate is a precursor to knowledge sharing. Marquardt (1996) identified employee interactions as channels that transmit and promote tacit knowledge sharing. Thus, social interactions develop employee-to-employee interactions and the tacit knowledge exchange process.

Organization work groups, mentor-mentee programs, and face-to-face social interactions naturally favor knowledge sharing behaviors. In these social interactions, members can "share information, ideas, discuss common issues and develop personal relationships" (Kim, 2015: p. 47). Organizations that promote cultures of sharing and trust facilitate transformation of tacit knowledge into explicit forms (Daland, 2016; Kim, 2015).

Formal and informal social interactions benefit tacit knowledge sharing. Tacit knowledge is not easily accessible using manuals, books, and policies. Tacit knowledge is personalized as expertise provides analytical rigorous advice (Smith, 2001). This explains why some employees may view sharing as a risk to their career or position. For example, an employee could feel that sharing knowledge may cost them a competitive advantage or promotion opportunity (Leonard \& Sensiper, 1998; Stenmark, 2000). Tacit knowledge sharing is informal and subjective in nature. It is not surprising that types of trust consistently yield significant contributions to the KM community and tacit knowledge sharing field.

Leaders who create knowledge-sharing environments motivate employees to share tacit knowledge (AlShamsi \& Ajmal, 2018). Employees who are motivated by knowledge sharing voluntarily support organizational goals and objectives (Hameed et al., 2019). Trust intensifies employee interactions and perceptions of fairness (Konovsky, 2000). Perceptions of fairness develop into employee trust (Cropanzano \& Mitchell, 2005). Environments that promote peer-to-peer trust should cultivate willingness to share tacit knowledge. This supports research findings by Nonaka et al. (1994) and Epstein (2000) that personal ties or relationships foster tacit knowledge exchanges among employees.

Social exchange theory (SET) posits that, as employees perceive benefit over 
cost, they are likely to exhibit desirable behaviors to co-workers. Gupta et al. (2020) confirmed this analysis and reported that employee perceptions of the cost of sharing tacit knowledge (CostTKS) negatively influenced willingness to share tacit knowledge (WSTK). Other studies have examined tacit knowledge sharing (TKS), focusing on peer relationships grounded in social interactions (Ganguly et al., 2019; Wu et al., 2016), emotional bonding (Zhang et al., 2015), and cooperation among employees with shared goals (Evans et al., 2018). There has been limited focus on quality social interactions that facilitate tacit knowledge holders to overcome psychological barriers (Gupta et al., 2020). Thus, studying KBT should contribute to knowledge on uncertainty reductions theory and improve understanding of employee-to-employee social interactions.

Holste and Fields (2010) reported that respect created a psychological condition that fostered an affect-based trust environment that was believed to encourage WSTK. Furthermore, SET suggests that employees are willing to share tacit knowledge with peers when they respect each other (Balogun \& Gabriel, 2015). However, rather than relying on SIT and SET, this research incorporated social interaction theory (SIT). SIT suggests that cost and benefit analysis motivates interpersonal interactions (Blau, 1964). Similarly, employee-to-employee respect encourages positive social interactions crucial for acquiring tacit knowledge (Wu et al., 2016). SIT has been widely used to examine peer-to-peer trust relationships. Thus, KBT will add to knowledge about SIT by measuring the employee-to-employee trust relationship on WSTK (Carnahan et al., 2017; Rupp \& Mallory, 2015).

There is a need for better understanding of factors that stimulate knowledge-sharing behaviors and empirically based recommendations to apply to knowledge sharing (Obrenovic et al., 2020). Prior research has shown how interpersonal connections strengthen knowledge-sharing behaviors (Milkman \& Berger, 2014). It is beneficial to focus on KBT interactions to contribute to understanding of interactions that minimize the cost of exchanging knowledge between employees.

Organizational studies have focused primarily on affect-based trust as an earnest relationship that influences WSTK (Holste \& Fields, 2010). Affect-based trust and cognition-based trust strengthen employee determinations to share tacit knowledge to help others to succeed (Friedman et al., 2018). Affect-based trust and cognition-based trust rely on respect and engender a positive feeling of self-worth in a group, leading to WSTK. KBT extends on previous views of social interactions based on affect-based and cognition-based trust as significant factors that enhance WSTK (An \& Ahmad, 2010; Gupta et al., 2020; Javernick-Will, 2011). Thus, KBT may introduce additional trust relationships to improve WSTK.

\subsection{Professional Relationship Trust}

McAllister's (1995) cognition-based and affect-based trust dominate the organizational trust field. Cognition-based trust accounts for overall organizational development and maintenance of employee relationships. Affect-based trust ac- 
counts for the emotional bond between employees that is generated over time (Gulati \& Sytch, 2008; Thomson et al., 2009). Most literature suggests that interpersonal trust and relationships are interchangeable. However, Lewicki and Bunker (1996) proposed that professional relationships are similar to friend or acquaintance affiliation and develop PRT stages derived from romantic relationship (Boon \& Holmes, 1991).

Lewicki and Bunker (1995) concluded that romantic forms of trust are essential in professional relationships and introduced a model for trust development stages: CBT, KBT, and IBT. CBT is based on written policies, procedures, punishments, and rewards to maintain trust. Written information contains explicit forms of knowledge. The focus of this investigation is tacit knowledge transfer. Thus, CBT is not idea in pursuit of trust that creates an environment for TKS.

IBT exists only after KBT. Lewicki and Bunker (1996) suggested that employees rarely reach this stage due to turnover, time on the job, or age of the company. IBT stages may reveal insight about trust as a mediator or moderator of affect-based trust on employee turnover. However, KBT is consistent with the view of social psychologists, where the primary focus is to observe interpersonal interactions among employees. This is similar to research on horizontal peer-to-peer interactions and tacit knowledge transfer (Connelly et al., 2012). However, Gupta et al. (2020) suggested that current approaches to the study of peer-to-peer interaction continue to limit understanding of TKS.

Some literature suggests that KBT could sometimes be referred to as relational trust (Rousseau, 2001). However, for continuity, the current research incorporated KBT definitions and measurements established by Lewicki and Bunker (1996) to ensure continuity and a clear approach to investigate the role of KBT ability in knowledge-sharing behaviors among employees.

\subsection{Knowledge-Based Trust}

KBT relationships to increase willingness to share information (Pugnetti \& Elmer, 2020). Mayer et al. (1995) defined KBT as a function of a person's perception of another's ability, integrity, and benevolence. KBT is viewed as a function of an employee's perception of another's trustworthiness. However, this is different than KBT as defined by Lewicki and Bunker (1996), that trust is developed though repeated employee-to-employee interactions.

Lewicki and Bunker (1996) suggested that employees at the KBT stage can begin to predict each other's behavior by gathering information. Employees possess the ability to predict coworker behavior and heighten the trust relationship. Employees who exhibit this type of KBT can predict both trustworthy and untrustworthy behavior based on repeated interactions. Thus, KBT provides a different approach by measuring face-to-face communication based on repeated interactions and predicting behaviors.

KBT requires regular communication to facilitate information exchange, preferences, and approaches to solving organization problems. Courtship permits 
each person to determine how well they may work with another person. Studies have confirmed that knowledge-based ownership strengthens the knowledge interaction and exchange process (Li et al., 2015; Sun et al., 2019). However, there is limited research on Lewicki and Bunker's KBT peer-to-peer cooperation approach. Based on the review of literature, the following hypothesis was posited.

H1: Knowledge-based trust is positively associated with willingness to share tacit knowledge.

\section{Methodology}

This section describes the overall validity and reliability of the independent variable KBT and the dependent variable WSTK. The section designates the approach to generate, collect, and analyze data for this investigation. In this cross-sectional, quantitative study, data were collected and analyzed to study the relationship between Lewicki and Bunker's (1996) KBT stage and Holste and Field's (2010) WSTK. A 7-item scale derived from Lewicki and Bunker (1996) and a modified scale by Saparito (2000) were used to measure KBT and an 8 -item scale derived from Holste and Field was used to measure WSTK. The survey asked respondents to indicate level of agreement to each item (strongly disagree, disagree, slightly disagree, neither agree nor disagree, slightly agree, agree, strongly agree).

The research followed general procedures of regression analysis. Pretests were not administered because each construct was defined and derived from multiple sources. Cronbach's alpha was used to measure scale reliability of the Likert-type scales. Correlation was used to investigate relationships between the independent and dependent variables. Linear regression was used to compare KBT and WSTK. The results tested the model fit to determine whether KBT significantly predicted WSTK.

\subsection{Independent Variable}

Knowledge-based trust. KBT is defined in this investigation as the stage at which each partner understands and predicts the other's thoughts and behavior. KBT is not based on control mechanisms but on repeated interactions over time (Lewicki \& Bunker, 1996). Partners gain understanding of each other's thoughts and behaviors. KBT was measured on a 7 items (e.g., "From past experiences, I can determine if my co-worker's ideas are reliable and from past experiences, I can predict my co-worker's reaction to certain job situations."

\subsection{Dependent Variable}

Willingness to share tacit knowledge. WSTK depends on how well each coworker trusts the source of information (Adler, 2002; De Long \& Fahey, 2000; Locke, 1999; Lucas, 2005; McAllister, 1995; Nahapiet \& Ghoshal, 1998; Scott, 2000; Tsai \& Ghoshal, 1998). Willingness to share knowledge is defined as a partner's readiness to share learned information verbally. The experience of each participant 
and interpersonal trust determine resistance or acceptance of knowledge flow into everyday usage by coworkers. WSTK is based on the measurement scale derived from Holste and Fields's (2010), containing 8 items (e.g. "I share rules of thumb and I am willing to share new ideas with my co-worker").

\subsection{Control Variables}

Age. Multiple studies (e.g., Strauss \& Howe, 1993; Tulgan, 1995) have suggested that younger workers may be less trusting than older workers. Thus, age may influence willingness to share and use tacit knowledge.

Gender. Carroll (2002) reported that gender had effects on trust when accepting tacit knowledge. The results suggested that women may be more willing than men to share and use tacit knowledge received from relationships. The current study survey asked for age and gender to evaluate these controls.

\section{Results}

The sample for this study consisted of full-time employees from private and commercial organizations in the United States. Employees were contacted via an Internet-based survey application; 250 agreed to participate. Of those 250 respondents, 215 provided demographic information. The sample consisted of 42.22\% males and $57.78 \%$ females (Table 1 ).

Summary statistics were calculated for KBT and WSTK. Each variable was within skewness and kurtosis ranges. When skewness is between -2 and +2 in absolute value, the variable is considered to be symmetrical about its mean. When the kurtosis is between -3 and +3 , the variable's distribution is normal and the tendency is to be free of outliers. Summary statistics are shown in Table 2.

IBM SPSS Statistics 25 was used to calculate Cronbach's alpha coefficients to, using guidelines suggested by George and Mallery (2016), where $>0.9$ is excellent, $>0.8$ is good, $>0.7$ is acceptable, $>0.6$ is questionable, $>0.5$ is poor, and $\leq 0.5$ is unacceptable (Table 3).

Based on acceptable Cronbach's alpha coefficients for each scale $(>0.8$ for KBT and $>0.9$ for WSTK), scale items were computed into KBT and WTSK to

Table 1. Sample size demographics.

\begin{tabular}{cc}
\hline Category & Percentage \\
\hline Gender & \\
Male & $42.22 \%$ \\
Female & 57.78 \\
Age & \\
$18-29$ & $14.00 \%$ \\
$30-44$ & $33.00 \%$ \\
$45-60$ & $44.00 \%$ \\
$>60$ & $9.00 \%$ \\
\hline
\end{tabular}


Table 2. Summary statistics for interval and ratio variables.

\begin{tabular}{ccccccccc}
\hline Variable & $\mathbf{M}$ & $\mathrm{SD}$ & $\mathbf{n}$ & $\mathrm{SE}_{\mathbf{M}}$ & Min & Max & Skewness & Kurtosis \\
\hline KBT & 25.55 & 7.27 & 250 & 0.37 & 5.00 & 35.00 & -0.59 & -0.40 \\
WSTK & 26.70 & 7.51 & 250 & 0.38 & 6.00 & 42.00 & -0.31 & -0.29 \\
\hline
\end{tabular}

Table 3. Knowledge-based trust and willingness to share measurement scale.

\begin{tabular}{ccc}
\hline Scale & Number of Items & Cronbach's Alpha \\
\hline KBT & 7 & .89 \\
WSTK & 8 & .95 \\
\hline
\end{tabular}

Table 4. Knowledge-based trust predicting willingness to share tacit knowledge.

\begin{tabular}{cccccc}
\hline Variable & B & SE & $B$ & t & $\boldsymbol{p}$ \\
\hline (Intercept) & 4.47 & 1.94 & 0.00 & 2.37 & $<0.007$ \\
KBT & 0.84 & 0.05 & 0.73 & 15.84 & $<0.000$ \\
\hline
\end{tabular}

Table 5. Age and gender control variable results.

\begin{tabular}{cccc}
\hline Variable & B & SE & p \\
\hline Gender & 0.49 & -0.023 & 0.733 \\
Age & 0.32 & 0.650 & 0.339 \\
\hline
\end{tabular}

test for correlation. KBT items were computed to the variable KBT and willingness to share items were computer to the variable WSTK.

KBT $p$-value was verified using linear regression on willingness to share. $\mathrm{Li}$ near regression was conducted on KBT and WSTK. First, the results indicated a significant positive relationship between KBT and WSTK, with a Pearson correlation.734, indicating that KBT had a significant relationship with WSTK, $p<$ 0.05 (Table 4).

Strauss and Howe's (1993) and Tulgan's (1995) research suggested that younger workers may be less trusting than older workers. Carroll's (2002) research suggested that same-gender interactions between females were more trusting with tacit knowledge information than were same-gender interactions between males. However, results from the current study provided evidence that age and gender were not significant factors $p>0.05$ (Table 5).

\section{Discussion}

\subsection{Theoretical Implications}

This study focused on peer-to-peer cooperation measured by KBT and WSTK. This section presents a discussion of theoretical and practical implications of KBT and WSTK. This study extends the uncertainty reductions theory (Berger \& Bradac, 1982; Berger \& Calabrese, 1975), which suggests that the more one knows a person, the more one can predict that person's behavior to examine the 
trustor-trustee relationship (McKnight et al., 2002).

The results indicated that KBT significantly predicted WSTK. However, KBT contradicts Shah and Mahmood's (2016) findings that trust is not significant within a tacit knowledge-sharing relationship. Conversely, KBT supported Endres and Rhoad's (2016) finding that repeat interactions promote tacit knowledge transfer.

The findings suggest that employees who exhibit KBT attributes have WSTK. This supports the premise that leaders and managers who promote desirable knowledge-sharing environments motivate tacit knowledge-sharing behaviors (AlShamsi \& Ajmal, 2018) and willingness to contribute knowledge to others (Hameed et al., 2019). Employee age (Strauss \& Howe, 1993; Tulgan, 1995) and same-gender interactions (Carroll, 2002) were not significant for employees who exhibited KBT attributes and WSTK. Thus, KBT advances understanding of KM trust relationships and employees' WSTK.

\subsection{Practical Implications}

KBT and WSTK. Leaders who encourage repeated employee-to-employee interactions will likely reduce employee hesitation to share tacit knowledge. KBT relationships allow employees to predict relationship behaviors. For example, Employee A continuously completes projects 3 days prior to Employee B deadlines. Based on KBT, Employee B begins to predict that Employee A will continue to complete tasks prior to deadlines. This promotes predictability and influences WSTK.

KBT supports that tacit knowledge is transmitted through social interactions (Agarwal \& Islam, 2014; Kennedy et al., 2012; Shao et al., 2016) and that employees voluntarily contribute toward organization success (Hameed et al., 2019). Thus, leaders and managers should invest in repeated employee-to-employee interactions to promote environments of trust that encourage WSTK.

\subsection{Limitations, Delimitations, and Significance}

This research involved limitations in using cross-sectional study methods. This approach cannot measure change in the relationship between employees over time. Participants in this study might have yielded different results after continuous interaction in the relationship. To measure change in the effects of trust levels on willingness to share, it would be beneficial to have additional cross-sectional studies of U.S. employees.

Research teams may find it difficult to determine whether participants are in the same stage of trust. For example, future results might reveal the presence of new employees in the job market, or previous participants might no longer be in the work force or might have retired. Changes in the sample and longevity of the trust relationship could cause an increase or decrease in trust results. Partners could end or start new trust partnerships based on the cited criteria, which could increase uncertainty about employee intentions or actions. 
There are possible sample biases in this study. The investigation could not measure the entire population. Data were collected from a subset of full-time employees; there may have been differences between the sample and the population. Permission letters were sent to the study population through SurveyMonkey $^{\mathrm{mm}}$. Participants may have rushed or may not have fully answered each question to the best of their knowledge. However, to mitigate this error, the measurement scale contained only 18 one-sentence items to address all variables and demographics in the study. The items were derived from previous validated and accepted studies to decrease survey item bias.

The KM community has significant evidence that tacit knowledge creates profitability, employee learning, and sustainability. Knowledge exchange occurs at the interpersonal level and deserves more attention in the scientific community, especially among economists, psychologists, and sociologists (Vasin, 2020). This research provided a systematic approach to investigate willingness to share, which could hinder tacit knowledge transfer. It was determined that KBT was associated with WSTK with co-workers.

\subsection{Future Research}

Leadership styles may mediate or moderate the relationship between PRT and tacit knowledge transfer. Studies of leadership styles may improve understanding of PRT and tacit knowledge transfer barriers. Learning about the relationship between leadership style and PRT could inform leaders, managers, and supervisors regarding styles that improve or degrade this trust relationship.

Gender and age were examined, and the results showed no significant effect on PRT stages. Future research should include other demographic categories to examine their possible influence on PRT and willingness to share. This would inform leaders, managers, and supervisors about the influence of group dynamics and organization diversity on trust relationships.

This study addressed employee willingness to share, which is a process that could hinder tacit knowledge transfer (Holste \& Fields, 2010). However, the researchers suggest that willingness to use tacit knowledge also hinders the exchange process. Thus, we recommend further research on KBT and the willingness to use tacit knowledge. This will fill the gap in the literature on types of trust that improve willingness to share and use tacit knowledge.

CBT and IBT were not considered in this research. More research should be done to measure the effect of CBT on explicit knowledge. IBT is rare due to employee turnover and age of the company. Further investigation is required to measure trust based on time with the company and age of the company.

\section{Conclusion}

Regardless of leadership KM practices, $76 \%$ of U.S. employees expressed hesitance to share tacit knowledge with co-workers (Pan et al., 2018). Thus, this investigation was conducted, using Lewicki and Bunker's (1996) KBT measure- 
ment scale and Holste and Field's (2010) WSTK. KBT significantly predicted WSTK between co-workers on the job. Age (Strauss \& Howe, 1993; Tulgan, 1995) and gender (Carroll, 2002) were not significant factors in the WSTK relationship. Because leaders strive to create and manage knowledge for competitive advantages in their industry (Gagné et al., 2019), promoting that KBT is likely to encourage employees' WSTK.

\section{Conflicts of Interest}

The author declares no conflicts of interest regarding the publication of this paper.

\section{References}

Adler, P. S. (2002). Market, Hierarchy, and Trust: The Knowledge Economy and the Future of Capitalism. In C. W. Choo, \& N. Bontis (Eds.), The Strategic Management of Intellectual Capital and Organizational Knowledge (pp. 100-131). New York: Oxford University Press.

Agarwal, N. K., \& Islam, M. A. (2014). Knowledge Management Implementation in a Library: Mapping Tools and Technologies to Phases of the KM Cycle. Vine, 44, 322-344. https://doi.org/10.1108/VINE-01-2014-0002

AlShamsi, O., \& Ajmal, M. (2018). Critical Factors for Knowledge Sharing in Technology-Intensive Organizations: Evidence from UAE Service Sector. Journal of Knowledge Management, 22, 384-412. https://doi.org/10.1108/JKM-05-2017-0181

An, M., \& Ahmad, H. S. (2010). Knowledge Management in Construction Projects: A Way Forward in Dealing with Tacit Knowledge. International Journal of Information Technology Project Management, 1, 16-42. https://doi.org/10.4018/jitpm.2010040102

Balogun, A. G., \& Gabriel, A. (2015). Willingness to Share and Use Tacit Knowledge among Employees in Team-Based Organisations: Are the Dimensions of Interpersonal Trust Facilitators? Information and Knowledge Management, 5, 100-107.

Bengtsson, M., \& Raza-Ullah, T. (2016). A Systematic Review of Research on Coopetition: Toward a Multilevel Understanding. Industrial Marketing Management, 57, 23-39. https://doi.org/10.1016/j.indmarman.2016.05.003

Bengtsson, M., Eriksson, J., \& Wincent, J. (2010). Co-opetition Dynamics: An Outline for Further Inquiry. Competitiveness Review: An International Business Journal, 20, 194-214. https://doi.org/10.1108/10595421011029893

Berger, C. R., \& Bradac, J. J. (1982). Language and Social Knowledge: Uncertainty in Interpersonal Relations. London, UK: Arnold.

Berger, C. R., \& Calabrese, R. J. (1975). Some Explorations in Initial Interaction and Beyond: Toward a Developmental Theory of Interpersonal Communication. Human Communication Theory, 1, 99-112. https://doi.org/10.1111/j.1468-2958.1975.tb00258.x

Blau, P. M. (1964). Exchange and Power in Social Life. Piscataway, NJ: Transaction Publishers.

Bogilovic, S., Cerne, M., \& Skerlavaj, M. (2017). Hiding Behind a Mask? Cultural Intelligence, Knowledge Hiding, and Individual and Team Creativity. European Journal of Work and Organizational Psychology, 26, 710-723.

https://doi.org/10.1080/1359432X.2017.1337747

Boon, S. D., \& Holmes, J. G. (1991). The Dynamics of Interpersonal Trust: Resolving Un- 
certainty in the Face of Risk. In R. A. Hinde, \& J. Groebel (Eds.), Cooperation and Prosocial Behavior (pp. 190-211). Cambridge, UK: Cambridge University Press.

Carnahan, S., Kryscynski, D., \& Olson, D. (2017). When Does Corporate Social Responsibility Reduce Employee Turnover? Evidence from Attorneys Before and after 9/11. Academy of Management Journal, 60, 1932-1962. https://doi.org/10.5465/amj.2015.0032

Carroll, M. N. (2002). Gender Differences in Trust and Loyalty within Single-Sex Friendships. New Orleans, LA: Loyola University.

Connelly, C. E., \& Zweig, D. (2015). How Perpetrators and Targets Construe Knowledge Hiding in Organizations. European Journal of Work and Organizational Psychology, 24, 479489. https://doi.org/10.1080/1359432X.2014.931325

Connelly, C. E., Zweig, D., Webster, J., \& Trougakos, J. P. (2012). Knowledge Hiding in Organizations. Journal of Organizational Behavior, 33, 64-88. https://doi.org/10.1002/job.737

Cropanzano, R., \& Mitchell, M. S. (2005). Social Exchange Theory: An Interdisciplinary Review. Journal of Management, 31, 874-900. https://doi.org/10.1177/0149206305279602

Daland, H. (2016). Managing Knowledge in Academic Libraries: Are We? Should We? LIBER Quarterly, 26, 28-41. https://doi.org/10.18352/lq.10154

De Long, D. W., \& Fahey, L. (2000). Diagnosing Cultural Barriers to Knowledge Management. Academy of Management Executive, 14, 13-27. https://doi.org/10.5465/ame.2000.3979820

Dietz, G., \& den Hartog, D. N. (2006). Measuring Trust inside Organisations. Personnel Review, 35, 557-588. https://doi.org/10.1108/00483480610682299

Dorn, S., Schweiger, B., \& Albers, S. (2016). Levels, Phases and Themes of Coopetition: A Systematic Literature Review and Research Agenda. European Management Journal, 34, 484-500. https://doi.org/10.1016/j.emj.2016.02.009

Edwards, D. C., Wong, M., Zhang, I. A., \& Wu, Q. J. (2017). Ambassadors of Knowledge Sharing: Co-Produced Travel Information through Tourist-Local Social Media Exchange. International Journal of Contemporary Hospitality Management, 29, 690-708. https://doi.org/10.1108/IJCHM-10-2015-0607

Endres, M. L., \& Rhoad, K. T. (2016). What Makes a High Performer Share Knowledge? Team Performance Management, 22, 269-283. https://doi.org/10.1108/TPM-05-2016-0022

Epstein, L. D. (2000). Sharing Knowledge in Organizations: How People Use Media to Communicate. Berkeley, CA: University of California.

Evans, M., Frissen, I., \& Wensley, A. K. (2018). Organisational Information and Knowledge Sharing: Uncovering Mediating Effects of Perceived Trustworthiness Using the PROCESS Approach. Journal of Information and Knowledge Management, 17, Article ID: 1850001.

Friedman, A., Carmeli, A., \& Dutton, J. E. (2018). When Does Respectful Engagement with One's Supervisor Foster Help-Seeking Behaviors and Performance? Journal of Vocational Behavior, 104, 184-198. https://doi.org/10.1016/j.jvb.2017.11.007

Gagné, M., Tian, A. W., Soo, C., Zhang, B., Ho, K. S. B., \& Hosszu, K. (2019). Different Motivations for Knowledge Sharing and Hiding: The Role of Motivating Work Design. Journal of Organizational Behavior, 40, 783-799. https://doi.org/10.1002/job.2364

Ganguly, A., Talukdar, A., \& Chatterjee, D. (2019). Evaluating the Role of Social Capital, 
Tacit Knowledge Sharing, Knowledge Quality and Reciprocity in Determining Innovation Capability of an Organization. Journal of Knowledge Management, 23, 1105-1135. https://doi.org/10.1108/JKM-03-2018-0190

George, D., \& Mallery, P. (2016). SPSS for Windows Step by Step: A Simple Guide and Reference (11.0 Update). Boston, MA: Allyn \& Bacon. https://doi.org/10.4324/9781315545899

Gulati, R., \& Sytch, M. (2008). Does Familiarity Breed Trust? Revisiting the Antecedents of Trust. Managerial and Decision Economics, 29, 165-190. https://doi.org/10.1002/mde.1396

Gupta, B., Wang, K. Y., \& Cai, W. (2020). Interactional Justice and Willingness to Share Tacit Knowledge: Perceived Cost as a Mediator, and Respectful Engagement as Moderator. Personnel Review, 50, 478-497. https://doi.org/10.1108/PR-08-2019-0436

Hameed, Z., Khan, I. U., Sheikh, Z., Islam, T., Rasheed, M. I., \& Naeem, R. M. (2019). Organizational Justice and Knowledge Sharing Behavior: The Role of Psychological Ownership and Perceived Organizational Support. Personnel Review, 48, 748-773. https://doi.org/10.1108/PR-07-2017-0217

Hitchen, E. L. N., Ferràs, P. A., \& Mussons, X. S. (2017). Social Media: Open Innovation in SMEs Finds New Support. Journal of Business Strategy, 38, 21-29. https://doi.org/10.1108/JBS-02-2016-0015

Holste J. S., \& Fields, D. (2010). Trust and Tacit Knowledge Sharing and Use. Journal of Knowledge Management, 14, 128-140. https://doi.org/10.1108/13673271011015615

Javernick-Will, A. (2011). Motivating Knowledge Sharing in Engineering and Construction Organizations: Power of Social Motivations. Journal of Management in Engineering, 28, 193-202. https://doi.org/10.1061/(ASCE)ME.1943-5479.0000076

Kennedy, J., Gubbins, C., \& Buckley, F. (2012). How Do Individuals Affect the Process of Managing Tacit Knowledge? In Proceedings of the European Conference on Knowledge Management, (Vol. 2, pp. 1411-1417). ECKM, Academic Publishing International.

Kim, J. (2015). Integrating Communities of Practice into Library Services. Collabora, 7, 47-55.

Konovsky, M. A. (2000). Understanding Procedural Justice and Its Impact on Business Organizations. Journal of Management, 26, 489-511. https://doi.org/10.1177/014920630002600306

Kumi, R., \& Sabherwal, R. (2018). Knowledge Sharing Behavior in Online Discussion Communities: Examining Behavior Motivation from Social and Individual Perspectives. Knowledge and Process Management, 26, 110-122. https://doi.org/10.1002/kpm.1574

Kwahk, K. Y., \& Park, D. H. (2016). The Effects of Network Sharing on Knowledge-Sharing Activities and Job Performance in Enterprise Social Media Environments. Computers in Human Behavior, 55, 826-839. https://doi.org/10.1016/j.chb.2015.09.044

Leonard, D., \& Sensiper, S. (1998). The Role of Tacit Knowledge in Group Innovation. California Management Review, 40, 112-132. https://doi.org/10.2307/41165946

Levin, D. Z., \& Cross, R. (2004). The Strength of Weak Ties You Can Trust: The Mediating Role of Trust in Effective Knowledge Transfer. Management Science, 50, 1477-1490. https://doi.org/10.1287/mnsc. 1030.0136

Lewicki, R. J., \& Bunker, B. B. (1995). Trust in Relationships: A Model of Development 
and Decline. In B. B. Bunker, \& J. Z. Rubin (Eds.), Conflict, Cooperation and Justice: Essays Inspired by the Work of Morton Deutsch (pp. 133-173). San Francisco, CA: Jossey-Bass.

Lewicki, R. J., \& Bunker, B. B. (1996). Developing and Maintaining Trust in Work Relationships. In R. M. Kramer, \& T. R. Tyler (Eds.), Trust in Organizations: Frontiers of Theory and Research (pp. 114-139). Thousand Oaks, CA: Sage. https://doi.org/10.4135/9781452243610.n7

Lewicki, R. J., McAllister, D. J., \& Bies, R. J. (1998). Trust and Distrust: New Relationships and Realities. Academy of Management Review, 23, 438-458. https://doi.org/10.5465/amr.1998.926620

Li, J., Ling, Y., Ning, L., \& Li-Ying, J. (2015). Knowledge Sharing and Affective Commitment: The Mediating Role of Psychological Ownership. Journal of Knowledge Management, 19, 1146-1166. https://doi.org/10.1108/JKM-01-2015-0043

Liu, Y., \& Phillips, J. S. (2011). Examining the Antecedents of Knowledge Sharing in Facilitating Team Innovativeness from a Multilevel Perspective. International Journal of Information Management, 31, 44-52. https://doi.org/10.1016/j.ijinfomgt.2010.05.002

Locke, E. A. (1999). Some Reservations about Social Capital. Academy of Management Review, 24, 8-9. https://doi.org/10.5465/amr.1999.15873796

Lucas, L. (2005). The Impact of Trust and Reputation on the Transfer of the Best Practices. Journal of Knowledge Management, 9, 87-101. https://doi.org/10.1108/13673270510610350

Marquardt, M. J. (1996). Building the Learning Organization. New York: McGraw-Hill.

Mayer, R. C., Davis, J. H., \& Schoorman, F. D. (1995). An Integrative Model of Organizational Trust. Academy of Management Review, 20, 709-734. https://doi.org/10.5465/amr.1995.9508080335

McAllister, D. J. (1995). Affect and Cognition-based Trust as Foundations for Interpersonal Cooperation in Organizations. Academy of Management Journal, 38, 24-59. https://doi.org/10.2307/256727

McEvily, B., \& Tortoriello, M. (2011). Measuring Trust in Organisational Research: Review and Recommendations. Journal of Trust Research, 1, 23-63. https://doi.org/10.1080/21515581.2011.552424

McEvily, B., \& Zaheer, A. (2005). Does Trust Still Matter? Research on the Role of Trust in Interorganizational Exchange. In R. Bachman, \& A. Zaheer (Eds.), Handbook of Trust Research (pp. 280-300). Cheltenham, UK: Edward Elgar.

McEvily, B., Perrone, V., \& Zaheer, A. (2003). Trust as an Organizing Principle. Organization Science, 14, 91-103. https://doi.org/10.1287/orsc.14.1.91.12814

McKnight, D. H., Choudhury, V., \& Kacmar, C. (2002). Developing and Validating Trust Measures for E-Commerce: An Integrative Typology. Information Systems Research, 13, 334-359. https://doi.org/10.1287/isre.13.3.334.81

Milkman, K., \& Berger, J. (2014). The Science of Sharing and the Sharing of Science. Proceedings of the National Academy of Sciences of the United States of America, 111, 13642-13649. https://doi.org/10.1073/pnas.1317511111

Nahapiet, J., \& Ghoshal, S. (1998). Social Capital, Intellectual Capital, and the Organizational Advantage. Academy of Management Review, 23, 242-266. https://doi.org/10.5465/amr.1998.533225

Nonaka, I. (1994). A Dynamic Theory of Organizational Knowledge Creation. Organization Science, 5, 14-37. https://doi.org/10.1287/orsc.5.1.14 
Nonaka, I., \& Takeuchi, H. (1995). The Knowledge-Creating Company: How Japanese Companies Create the Dynamics of Innovation. London, UK: Oxford University Press. https://doi.org/10.1016/0024-6301(96)81509-3

Nonaka, I., Byosiere, P., Borucki, C. C., \& Konno, N. (1994). Organizational Knowledge Creation Theory: A First Comprehensive Test. International Business Review, 3, 337-351. https://doi.org/10.1016/0969-5931(94)90027-2

Obrenovic, B., Jianguo, D., Tsoy, D., Obrenovic, S., Khan, M. A. S., \& Anwar, F. (2020). The Enjoyment of Knowledge Sharing: Impact of Altruism on Tacit Knowledge-Sharing Behavior. Frontiers in Psychology, 11, 1496-1496.

https://doi.org/10.3389/fpsyg.2020.01496

Okazaki, S. A., \& Campo, L. S. (2017). Knowledge Sharing among Tourists via Social Media: A Comparison between Facebook and Tripadvisor. International Journal of Tourism Research, 19, 107-119. https://doi.org/10.1002/jtr.2090

Pan, W., Zhang, Q., Teo, T., \& Lim, V. (2018). The Dark Triad and Knowledge Hiding. International Journal of Information Management, 42, 36-48. https://doi.org/10.1016/j.ijinfomgt.2018.05.008

Park, J., \& Gabbard, J. L. (2018). Factors That Affect Scientists' Knowledge Sharing Behavior in Health and Life Sciences Research Communities: Differences between Explicit and Implicit Knowledge. Computers in Human Behavior, 78, 326-335.

https://doi.org/10.1016/j.chb.2017.09.017

Polanyi, M. (1966). The Tacit Dimension. London, UK: Routledge \& Kegan Paul.

Pugnetti, C., \& Elmer, S. (2020). Self-Assessment of Driving Style and the Willingness to Share Personal Information. Journal of Risk and Financial Management, 13, 53.

https://doi.org/10.3390/jrfm13030053

Razmerita, L. K., \& Nielsen K. P. (2016). What Factors Influence Knowledge Sharing in Organizations? A Social Dilemma Perspective of Social Media Communication. Journal of Knowledge Management, 20, 1225-1246. https://doi.org/10.1108/JKM-03-2016-0112

Rousseau, D. M. (2001). Schema, Promise and Mutuality: The Building Blocks of the Psychological Contract. Journal of Occupational and Organizational Psychology, 74, 511-541. https://doi.org/10.1348/096317901167505

Rupp, D. E., \& Mallory, D. B. (2015). Corporate Social Responsibility: Psychological, Person-Centric, and Progressing. Annual Review of Organizational Psychology and Organizational Behavior, 2, 211-236. https://doi.org/10.1146/annurev-orgpsych-032414-111505

Saparito, P. (2000). Three Dimensions of Trust in Bank-Small Firm Relationships: Instrument Development and Preliminary Examination of the Production of Trust by Various Organizational Structures. Paper presented at the Babson College Entrepreneurship Research Conference (BCERC), Wellesley, MA, June 2000.

Scott, J. (2000). Facilitating Interorganizational Learning with Information Technology. Journal of Management Information Systems, 17, 81-113. https://doi.org/10.1080/07421222.2000.11045648

Shah, S. R., \& Mahmood, K. (2016). Contributing Factors in Knowledge Sharing for Performance of University Students in Teachers' Training Programs. Library Management, 37, 496-506. https://doi.org/10.1108/LM-09-2016-0067

Shao, Z., Feng, Y., Wang, T., \& Liu, L. (2016). The Impact Mechanism of Charismatic Leadership on Individuals' Tacit Knowledge Sharing. The Fifteenth Wuhan International Conference on E-Business-IT Project Management, 7, 527-534. 
Shen, H., \& Wang, G. (2017). Can Dynamic Knowledge-Sharing Activities Be Mirrored from the Static Online Social Network in Yahoo? Answers and How to Improve Its Quality of Service. IEEE Transactions on Systems, Man \& Cybernetics: Systems, 47, 3363-3376. https://doi.org/10.1109/TSMC.2016.2580606

Smith, E. A. (2001). The Role of Tacit and Explicit Knowledge in the Workplace. Journal of Knowledge Management, 5, 311-321. https://doi.org/10.1108/13673270110411733

Spender, J. C., \& Grant, R. M. (1996). Knowledge and the Firm: Overview. Strategic Management Journal, 17, 5-9. https://doi.org/10.1002/smj.4250171103

Stenmark, D. (2000). Leveraging Tacit Organizational Knowledge. Journal of Management Information Systems, 17, 9-24. https://doi.org/10.1080/07421222.2000.11045655

Strauss, W., \& Howe, N. (1993). 13th Gen: Abort, Retry, Ignore, Fail? New York: Vintage Books.

Sun, H., Zhang, L., \& Meng, J. (2019). Alleviating Knowledge Contribution Loafing among Engineering Designers by Ethical Leadership: The Role of Knowledge-Based Psychological Ownership and Emotion Regulation Strategies. Journal of Knowledge Management, 24, 235-257. https://doi.org/10.1108/JKM-06-2019-0301

Sweeney, G. (1996). Learning Efficiency, Technological Change and Economic Progress. International Journal of Technology Management, 11, 5-27.

Teece, D. J. (2000). Managing Intellectual Capital: Organizational, Strategic, and Policy Dimensions. London, UK: Oxford University Press.

Teece, D. J., Pisano, G., \& Shuen, A. (1997). Dynamic Capabilities and Strategic Management. Strategic Management Journal, 18, 509-533.

https://doi.org/10.1002/(SICI)1097-0266(199708)18:7<509::AID-SMJ882>3.0.CO;2-Z

Thomson, A. M., Perry, J. L., \& Miller, T. K. (2009). Conceptualizing and Measuring Collaboration. Journal of Public Administration Research and Theory, 19, 23-56.

https://doi.org/10.1093/jopart/mum036

Tsai, W., \& Ghoshal, S. (1998). Social Capital and Value Creation: The Role of Intrafirm Networks. Academy of Management Journal, 41, 464-476.

https://doi.org/10.2307/257085

Tulgan, B. (1995). Managing Generation X. Santa Monica, CA: Merritt.

Vasin, S. M., Gamidullaeva, L. A., Wise, N. A., \& Korolev, K. Y. (2020). Knowledge Exchange and the Trust Institution: A New Look at the Problem. Journal of the Knowledge Economy, 11, 1026-1042. https://doi.org/10.1007/s13132-019-00588-2

Wu, M., Sun, X., Zhang, D., \& Wang, C. (2016). Moderated Mediation Model of Relationship between Perceived Organizational Justice and Counterproductive Work Behaviour. Journal of Chinese Human Resource Management, 7, 64-81. https://doi.org/10.1108/JCHRM-07-2016-0016

Zhang, C., Xiao, H., Gursoy, D., \& Rao, Y. (2015). Tacit Knowledge Spillover and Sustainability in Destination Development. Journal of Sustainable Tourism, 23, 1029-1048. https://doi.org/10.1080/09669582.2015.1032299

Zhou, S., Siu, F., \& Wang, M. (2010). Effects of Social Tie Content on Knowledge Transfer. Journal of Knowledge Management, 14, 449-463. https://doi.org/10.1108/13673271011050157 